\title{
BIOGRAFIA E AUTOBIOGRAFIA: TANGÊNCIAS E SECÂNCIAS
}

\section{ANTONIO VALVERDE ${ }^{2}$}

RESUMO: O ensaio intenta problematizar e circunscrever os termos "biografia" e "autobiografia", histórica e filosoficamente. Para tanto interroga pelos usos e apropriações,

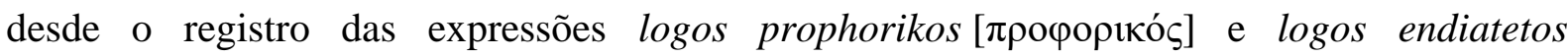

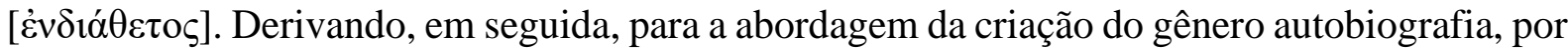
hipótese iniciada a meados do século XIII, com Marco Polo, com destaques para as escritas ao tempo do Renascimento, de Cellini e de Cardano, sob o arco da extroversão a apontar para a introversão dos modernos, conforme Agnes Heller. Ao final, o ensaio analisa alguns formatos de biografias registradas a várias mãos e a cinematográfica. Além de referências às autobiografias bem concertadas, de Vico, Goethe, Rousseau, Darwin, e à poética de Walt Whitman.

PALAVRAS-CHAVE: Logos interno; logos exterior; biografia; autobiografia; Renascimento; filme.

\begin{abstract}
The essay attempts to problematize and circumscribe the terms "biography" and "autobiography", historically and philosophically. For this purpose, he inquires about the uses

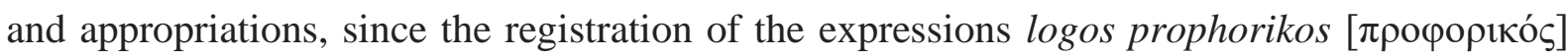

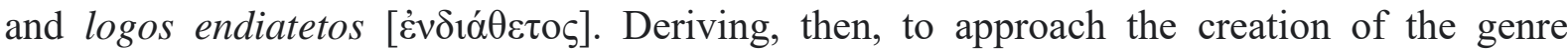
autobiography, by hypothesis started in the middle of the 143th century, with Marco Polo, with highlights for the writings at the time of the Renaissance, Cellini and Cardano, under the arc of extroversion to point out for the introversion of moderns, according to Agnes Heller. In the end, the essay analyzes some formats of biographies recorded by various hands and the cinematographic. In addition to references to the well-concerted autobiographies by Vico, Goethe, Rousseau, Darwin, and the poetics of Walt Whitman.
\end{abstract}

KEYWORDS: Internal logos; exterior logos; biography; autobiography; Renaissance; film.

\footnotetext{
${ }^{1} \mathrm{O}$ ensaio em tela, ora revisto e ampliado, foi publicado, originalmente, sob o título de "Biografia e autobiografia: tangências da exterioridade e da interioridade”, In FÁVERO, A. A.; PAVIANI, J.; RAJOBAC, R. (Org.), Vínculos Filosóficos: homenagem a Luiz Carlos Bombassaro, Caxias do Sul, Educs, 2020, pp. 301-315. Lança-se mão de propriedades geométricas para fins figurativos: a tangência entre entes geométricos ocorre quando existe um único ponto comum (entre eles); para a secância, há no mínimo dois pontos comuns entre os entes geométricos. Agradeço ao amigo Jorge Sallum as ótimas conversas acerca dos temas do ensaio.

2 Professor Titular do Departamento de Filosofia da Pontifícia Universidade Católica de São Paulo (PUC-SP). Líder do Grupo de Pesquisa "Renascimento, ética, política e religião" pela PUC-SP/CNPq. Líder do Grupo de Pesquisa "Filosofia Contemporânea" pela PUC-SP/CNPq. Doutor em Educação pela Universidade Estadual de Campinas (UNICAMP). E-mail: valverde@ pucsp.br.
} 
When I read the book, the biography famous, And is this then (said I) what the author calls a man's life?

And so will some one when I am dead and gone write my life?

(As if any man really knew aught of my life,

Why even I myself I often think know little or nothing of my life,

Only a few hints, a few diffused faint clews and indirections

I seek for my own use to trace out here). (Walt Whitman, "When I read the Book", Leaves of Grass) ${ }^{3}$

\section{A invenção da biografia em questão}

Há uma vaga de biografias no mercado editorial, desde a onda norte-americana de biografar artistas de sucesso ou sem sucesso, políticos, empresários, medalhões, que mais parecem incorporar o personagem Janjão, de Machado de Assis, mostrado no conto Teoria do Medalhão. Em que parte significativa dos interessados pagam para serem biografados por biógrafos profissionais. Em outros casos, a indústria cultural projeta o futuro sucesso editorial com a criação de uma imagem pasteurizada do sujeito a ser retratado, espalhada pelas redes sociais em escala amplificada. As biografias de artistas parecem seguir o movimento esperado: nascimento desfavorecido, desenvolvimento de talentos vencendo todas as vicissitudes, experiências amorosas fracassadas, estagiando em drogas pesada, morte com lances de tragédia anunciada, contrapostas ao gesto de criar obras artísticas de gosto suspeito. Para o caso dos políticos: projetos mesquinhos muito aquém do bem público e, dos empresários, jogadas de mercado suspeitíssimas. Aos medalhões vale o tornar-se figura necessária em eventos sociais da melhor sociedade, na maioria desnecessários, como vaticinara o Pai do personagem Janjão, com a finalidade de entusiasmar o filho a vencer na vida sem fazer força. Recorde-se que ele poderia, se desejasse, entrar para a política, desde que não atrelasse nenhuma ideia ao nome do partido político escolhido. - Tema de pauta extensiva.

Porém, em Inglaterra, encontra-se em andamento uma discussão acerca do esgotamento do gênero literário biografia. Noticiada pela Folha de São Paulo, ${ }^{4}$ a matéria informa que não haveria mais filósofos, artistas, nobres, políticos, militares, religiosos e

\footnotetext{
3 “Quando li o livro, a famosa biografia, / É isso, então (eu disse), que o autor chama de uma vida humana? / Então quando eu morrer alguém vai escrever a minha vida? / (Como se qualquer homem soubesse de fato alguma coisa da minha vida? / Pois eu mesmo muitas vezes me dou conta de quão pouco ou nada sei da minha vida real, / Apenas alguns palpites, umas poucas e difusas pistas, coisas indiretas, / Pretendo, para uso próprio, traçar aqui). (WHITMAN, 1892 / 2011, p. 30)

${ }^{4}$ Matéria da Folha de São Paulo, de 24 de junho de 2018, intitulada "A morte da biografia?", seguida do destaque, em subtítulo, "sinais de esgotamento de grandes personagens sugerem o que o caminho é retratar gente comum", por Christian Schwartz.
} 
notáveis, desde os primórdios da Modernidade até a atualidade, a terem suas vidas descortinadas por habilíssimos pesquisadores e escritores especializados. O gênero biografia (sic) fora consagrado por Plutarco, Suetonio, Cornelius Nepos, Diôgenes Laêrtios, Porfírio, ${ }^{5}$ Vasari e outros tantos, a retratar as vidas de homens ilustres. Talvez a crise, quiçá momentânea do gênero, ofereça oportunidade de reflexão acerca da invenção da tradição biográfica pelos antigos e da retomada pelos italianos da Idade Média, além da reinvenção da autobiografia desde o século XIII, tanto a documental quanto a ficcional, como gênero literário emparelhado e complementar da biografia, marca da nascente individualização, sob o teto da secularização e, por certo, da filosofia nominalista.

Alguns cuidados iniciais. Os antigos não costumavam misturar bios, "vida", com biografia. Sobremaneira, porque grafos é um termo ligado à lei e à pintura, ou, concretamente, ao traço que define. Imagine-se uma pessoa tentando escrever na pedra, eis o gesto graphein, de grafar. O termo seria entendido mais, especificamente, como lei da vida ou pintura da vida, o que sugeriria um possível título a um filme de humor do grupo Mounty Pithon!

Também, os termos biógrafo ou biografia parecem ser, totalmente, alheios à Antiguidade. Aqui a certeza claudica, porque não há referências explícitas nos dicionários “clássicos" de Latim e de Grego para tais termos. Entanto, a hagiografia parece ser a expressão da bios colocada para si mesmo, vez que Meditações, de Marco Aurélio, se intitula eis to hemauto, "para mim mesmo". A autobiografia não seria assim um relato sobre si mesmo contado para os outros, mas, sim, para o próprio autor. O resultado deveria ser a observação de uma espécie de oratio cristã. Obviamente, oratio é oração, mas também discurso, daí orator, o orador. Um imperador que carrega consigo o mundo inteiro para uma oratio, logo, "consigo mesmo" mostra a delicadeza desse tipo de exercício estoico, de encontro, confronto das coisas do mundo com a percepção, katalepsis. De certa forma, os platônicos associam a katalepsis estoica com um logos endiathetos. Não é incomum encontrar essa questão associada à poesia por exemplo, em que poema figura como o resultado de um fazer, enquanto empoema desponta como o feito "dentro de si”, em silêncio. A hagiografia fornece a forma do homem retirado, em silêncio, em viagem errática, pelo erro e pelo percurso. Por certo, aí encontra-se a alcova de Descartes, que no calor do seu quartinho (le poêle) percorre o método da dúvida metódica. Acaso, Montaigne e Rousseau irão pela mesma via? Montaigne, muito mais como um desdobramento da segunda sofística, em que o filósofo retor opera um discurso

\footnotetext{
${ }^{5}$ Filósofos "biógrafos" como Porfírio, Jâmblico, Marino e Damáscio, leem "as vidas de maneira alegórica, isto é, como introdução alegórica da doutrina platônica, em que todos os fatos da vida dos filósofos sejam ou possam ser lidos em segundo sentido, (pois) lançam os fatos no campo amplo do duplo sentido (SALLUM, 2012, p. 57)."
} 
para provocar o público a exercitar a arte de "pensar", como uma arte de ouvir o político e não se portar como político. Será que essa matriz tem a ver com a bios? Há que se suspender o juízo acerca de Rousseau. As Confissões, claramente, parecerem remeter a Boécio, antes até a Agostinho. Mas não seriam, Montaigne e Rousseau, exatamente o contrário de uma hagiografia? A questão não estando no homem, mas entre os homens?

A par das biografias conhecidas da Antiguidade, escritas por Plutarco e correligionários, há também as escritas por filósofos biógrafos como Porfírio, Jâmblico, Marino e Damáscio, menos divulgadas, que liam "as vidas de maneira alegórica, isto é, como introdução alegórica da doutrina platônica, em que todos os fatos da vida dos filósofos sejam ou possam ser lidos em segundo sentido, (pois que) lançam os fatos no campo amplo do duplo sentido (SALLUM, 2012, p. 57).” Destaques para Vita Plotini, escrita por Porfírio e a Vita Procli, de Marino, em que a questão de fundo parece ser a biografia que espelha somente a

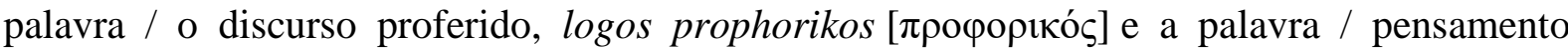

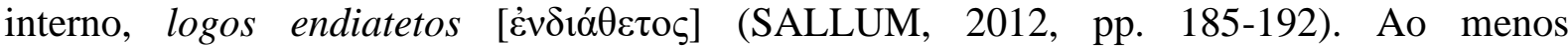
metaforicamente. Sob o contexto do século XIV, tratando de coletâneas biográficas de homens e mulheres ilustres, Burckhardt registra que, apesar da caracterização breve, era "notável especialmente por condensar as fisionomias externas e internas dos biografados (BURCKHART, 1991, p. 243)." - Como hipótese, eis a pergunta fundante a perpassar a escrita e a leitura de biografias e de autobiografias: o que se põe em questão, a verdade da "alma" ou a verdade dos "fatos" da vida do biografado? Ou a alegorização da vida?"

Porfírio ilustra o duplo jogo entre aparência e, diga-se, essência do indivíduo cuja vida contada, desde a constatação anedótica de que Plotino não desejava ser retratado por Amélio. O argumento de Plotino parece forte e razoável, porque "parecia envergonhar-se de estar em um corpo. Devido a tal disposição, não suportava falar nem de sua origem, nem de seus pais, nem de sua pátria. Tolerar um pintor lhe parecia tão indigno a ponto de responder a Amélio, que lhe pedira permissão para que se fizesse um retrato dele: 'Pois não basta carregar a imagem com que a natureza nos revestiu, mas ainda devo concordar em legar uma imagem mais duradoura da imagem, como se essa fosse de fato alguma das obras dignas de serem contempladas?' (PORFÍRIO, BACARAT, 2006, p. 163; SALLUM, 2012, p. 58).” O fundo

\footnotetext{
${ }^{6}$ Ora, a bios dos antigos "fala" muito de viagens, mas de uma viagem alegórica. Proclo, segundo Marino, viajou e à cada cidade parece representar uma hipóstase, ou um encontro com alguma doutrina a ser posta a prova eis tou biou, "para a vida". Mas não são viagens de reconhecimento de terreno ou de descobertas de riquezas. Esse gênero também existia na Antiguidade, mas era algo mais próprio de Heródoto e, portanto, da historía kaí emporía, do saber e do comercializar. Parece que ao tempo do Renascimento os relatos de viajantes têm algo de alegórico ainda, por buscar o novo, a nova etapa, a nova doutrina que é interpretada pela opsis (visão) do viajante em relato ecfrástico (descritivo), mas sobretudo, incorporado à História. Eis a novidade!
} 
platônico do argumento relembra que a forma pura não pode ser realizada de modo sensível. O artifício do pintor Amélio foi a de enviar o amigo Carterio, tornado espião das "reuniões" abertas que o Filósofo oferecia, para observá-lo, atentamente, e relatar detalhes da sua fisionomia, da expressão do olhar, da postura, dos gestos. Resultado: um retrato excelente, tal qual o retratado, mesmo sem tê-lo como modelo exposto durante o tempo necessário para tal elaboração. No limite da exterioridade da expressão revelada do Filósofo. Porém, não a da sua interioridade, da sua alma. A vida de Plotino pode ser considerada "a mais alegórica das vidas, [...] uma verdadeira sequencia ininterrupta de fatos metafóricos, que ilustram a dualidade entre o silêncio do logos interno e o ruído de um logos exterior (SALLUM, 2012, p. 57).”

Ao tempo da civilização do Renascimento, como que em paralelo, Michelangelo, sob inspiração neoplatônica, deixara inacabada algumas esculturas, sob o argumento da impossibilidade de realização da forma pura. Argan, o arco da crítica contemporânea, nomeou tal atitude, desesperada, por non finito, a dificuldade teórico-prática de avançar na composição da forma pura por sobre da matéria sensível. Pois, o "non finito é uma qualidade do estilo plástico de Michelangelo, uma exigência de sua poética neoplatônica, a expressão de sua impaciência com o limite da matéria e da própria forma, diante da transcendência do 'conceito' (ARGAN, 1999, p. 296)."7

Contudo, antes de Porfírio, com licença poética, Virgílio biografou Eneias, herói do poema Eneida, filho de Vênus, a Afrodite romana, - que, conforme a Teogonia, de Hesíodo, nascida do sangue do falo decepado de Saturno (Cronos) e da espuma do mar; deusa do encanto amoroso, que em mitos tardios ressurge como mãe de Eros / Cupido -, e do mortal Anquises. Ao passo que o próprio Virgílio fora biografado por Donatus (BURCKHARDT, 1991, p. 243). Frente ao longo poema Eneida, de finíssima imaginação literária, a Ilíada, de Homero, parece tornar-se um suporte necessário da construção de tal altura poética, histórica, cívica, a retratar a vida do ilustre troiano / romano. Contudo, como quer Tito Lívio, se há historiadores que tomam em conta a favole poetiche para justificar a fundação de Roma, ${ }^{8}$ ele, porém, não confirma e nem contesta tal remissão. Mas, como consta das páginas iniciais de $A b$ Urbe

\footnotetext{
${ }^{7}$ Argan prossegue argumentando que: "Nesse sentido ele foi estudado, no âmbito, porém, das obras singulares que parecem, mas não são inacabadas, porque o são apenas em relação a um processo técnico que não alcança seu fim de mimesis e o transfere continuamente - da mimese da coisa para a mimese da ideia (ARGAN, 1999, P. 296).”

${ }^{8}$ Tito Lívio escreveu: "I racconti tradizionali che si riferiscono ai tempi precedenti la fondazione o la futura fondazione dell'Urbe, conformi più alle favole poetiche che a una rigorosa documentazione storica, io non intendo né confermarli né confutarli. Si può ben accordare agil antichi questa licenza di nobilitare le origini delle città mescolando l'umano col divino; e se v'è un popolo cui si deve consentire di divinizzare le proprie origini e di attribuirne la causa prima agli dèi, il popolo romano ha tale gloria militare che, quando esse vanta sopratutto Marte come padre suo e del suo fondatore, le genti accetano di buon animo questa sua debolezza cosí come ne accetano il domínio (TITO LÍVIO, 1997, pp. 225 e 227).”
} 
Condita Libri, Tito Lívio confirma Eneias fundador de Roma. ${ }^{9}$ Em verdade, Eneias antes de dominar a cena da Eneida fez presença efêmera na Ilíada, e foi nomeado no Hino a Afrodite, nos versos em que a deusa tranquiliza o pai de Eneias: “- Anquises, o mais nobre dos homens mortais, coragem! / E que teu espírito não se inquiete terrivelmente; / não tenhas, pois, receio de sofrer algum mal de mim, / nem dos demais Bem-Aventurados, pois é amado pelos deuses. / Tu terás um filho amado, que reinará sobre Troia, / e continuamente filhos nascerão de seus filhos. / Eneias será seu nome, porque uma terrível aflição me invade, / por ter caído no leito de um homem mortal (h.Hom. 5, 2010, versos 192-199)."

Em verdade, os primeiros versos do poema dão conta da gesta de Eneias, das ruínas de Troia à gênese da civilização romana:

\begin{abstract}
As armas canto e o varão ${ }^{10}$ que, fugindo das plagas de Troia por injunções do Destino, instalou-se na Itália primeiro e de Lavínio nas praias. A impulso dos deuses por muito tempo nos mares e em terras vagou sob as iras de Juno, guerras sem fim sustentou para as bases lançar da cidade e ao Lácio os deuses trazer - o começo da gente latina, dos pais albanos primevos e muros de Roma altanados.

Musa!, recorda-me as causas da guerra, a deidade agravada; por qual ofensa a rainha dos deuses levou um guerreiro tão religioso a enfrentar em descanso esses duros trabalhos? Cabe tão fero rancor no imo peito dos deuses eternos? Cidade antiga existiu, dos colonos de Tiro povoada, forte Cartago, distante da Itália e das bocas do Tibre, rica de todo comércio, de grande maldade na guerra.
\end{abstract}

(VIRGÍLIO, Eneida, I, 1-15, 2014)

Para o caso da retomada da biografia, Burckhardt anotou: "fora dos domínios da poesia, os italianos foram os primeiros dentre os europeus a revelar propensão e talento marcados para retratar com precisão o homem na história, de acordo com seus traços e qualidades tanto exteriores quanto interiores. [...] Entre os italianos, a busca de traços característicos de homens ilustres torna-se, então, uma tendência predominante, e é isso que os diferencia dos demais ocidentais, em meio aos quais essa tendência manifesta-se apenas acidentalmente e somente em casos extraordinários. Um senso tão desenvolvido para a individualidade, só pode possuí-lo aquele que se destacou ele próprio de sua coletividade, tornando-se assim um indivíduo (BURCKHARDT, 1991, p. 242)".11

\footnotetext{
${ }^{9}$ A propósito dos primórdios da fundação de Roma e do lugar histórico de Eneias, conferir TITO LIVIO, Libro Primo, 1, 2 e 3, 1997, pp. 229, 231, 233 e 235.

${ }^{10}$ Eneias é o varão referido.

${ }^{11}$ Historiando. Os termos biographer e biography são assim usados, durante o século XVIII, para um tipo de história romanceada didática, como registrado na antiga Britânica, de 1771. A noção não se distancia daquela didática, que é a principal função das vidas dos filósofos, desde a Antiguidade, a de apresentar a filosofia ao jovem desde a própria vida alegorizada do filósofo. O termo biografia aparece, em França, de par com biógrafo, e pelo
} 


\section{A invenção da autobiografia}

Se na Antiguidade e na Idade Média existiram poucos tipos sociais capazes de oferecerem real interesse de modo a terem suas vidas registradas por biógrafos, uma vez que somente homens ilustres como reis, heróis, santos, - universais concretos no dizer de Hegel -, mereceriam ser biografados, individualmente ou em coletâneas, à aurora do mundo moderno, ainda no século XIII, trouxe consigo o registro que pode ser considerada a primeira autobiografia com características inovadoras, a Vita Nuova, de Dante Alighieri, pela força da interioridade e o Livro das Maravilhas, de Marco Polo, pela exterioridade. Sem desconsiderar as Confissões, de Agostinho de Hipona, autobiografia escrita ao final do século IV, entre 397 e 400, ao relatar o caminho do particular Aurélio Agostinho em movimento de encontro com Cristo. Heller escreveu que as "Confissões de Santo Agostinho são a primeira autobiografia verdadeira (HELLER, 1982, P. 191).” A propósito, Agostinho registrou que os "treze livros das minhas Confissões louvam o Deus justo e bom por meus males e bem, e elevam até ele a mente e o coração dos homens; senti esse efeito enquanto as escrevia, e torno a senti-lo cada vez que as leio", que se lê em Retractationes II, 6 (FRANGIOTTI, In AGOSTINHO, 1997, p. 9). Os livros de as Confissões são marcados por uma ruptura, pois os nove primeiros têm carácter autobiográfico, ao passo que os livros X-XIII não seriam propriamente confissões, vez que o livro X mostra a análise das motivações pessoais à escrita deste, e, os XI-XIII, trazem comentários à parte inicial do Genesis. ${ }^{12}$

Heller considera que, ao final do Império Romano, "se desenvolveram pela primeira vez, num breve período de tempo, as condições prévias da autobiografia, dando origem às Confissões de Santo Agostinho", em que se encontram "um mundo representativo e uma personalidade significativa, como ainda um mundo dinâmico com um sistema pluralista de valores e um indivíduo preparado para escolher o seu caminho nesse mundo." Contudo, por "muitas palavras que Agostinho possa dirigir a Deus [...] e argumentos religiosos que possam interromper a narrativa da sua vida, esta obra é, como autobiografia, tipicamente terrena

visto com sotaque inglês. Mas, somente ganham essa noção de vida da "pessoa" no começo do século XIX. No Dictionnaire Historique de la Langue Française, nada é encontrado de muito preciso, mas, fica claro que essa coisa de levar a "vida", da dispositio para a inventio figuram, certamente, como uma operação romântica. Desse ponto de vista, Hegel e também Burckhardt, provavelmente, operaram com tal dispositivo, porque fizeram surgir a "grande figura histórica", que não comparecia aos relatos das vidas de filósofos.

${ }^{12}$ Ligando passagens anteriores referidas aos platônicos, no entanto, sem desenvolver neste ensaio, registra-se que Agostinho: "Descobre a existência do sentido espiritual que se ocultava sob o sentido literal das Escrituras. A leitura dos 'platônicos', Porfírio, e uma parte das Eneadas de Plotino, o inicia na reflexão do espírito sobre si mesmo e o liberta da concepção materialista de Deus. Esse encontro com a metafísica platônica aclarou seu pensamento, fugiram-lhe as dúvidas e o ceticismo. Descobre o eterno e imutável, a realidade imaterial transcendente (FRANGIOTTI, In AGOSTINHO, 1997, p. 11).” 
(HELLER, 1982, p. 193)."13 De qualquer modo, as luzes da sua vida pessoal ficaram, de certa forma, em segundo plano, realçada a do lançar-se em direção à vivência da mensagem cristã, de modo pleno segundo seu entendimento.

A propósito da autobiografia entre os italianos, Burckhardt apontou que também "a autobiografia alça, por vezes, voos amplos e vigorosos entre os italianos, paralelamente a uma variegada vida exterior, descrevendo com profundidade também a vida interior de seu autor [...]. (Assim) é como se a Vita Nuova de Dante, em sua verdade inexorável, tivesse mostrado o caminho à nação (BURCKHARDT, 1991, p. 245).” Dante (1265-1321), poeta filósofo como Lucrécio e Goethe, escreveu Vita Nuova, entre 1292 e 1293, em verdade, uma autobiografia, narrativa de si, desde a experiência do amor a Beatrice Portinari, la donna gentile, recém falecida. Escrita na forma de sonetos, poemas, intercalados de reflexões sobre tais, a movimentar-se entre aspectos ficcionais e, talvez, documentais. O luto fora transformado em condição poética de aceitação e de superação da morte, em vista de uma nova condição de vida, "Incipit vita nova", sem a beleza e o amor encarnados na figura de Beatrice. Quando de seu primeiro encontro, Dante relembra: "dela se podia dizer a palavra do poeta Homero: 'Não parecia filha de homem mortal, mas de Deus"'. Em outra passagem, desiludido da companhia de outras mulheres, registra: "Poucos dias depois, sucedeu que, em uma parte da minha pessoa, me veio uma dolorosa enfermidade, pela qual sofri continuamente, por nove dias, amaríssima pena; a qual me levou a tanta debilidade, que eu era obrigado a ficar como aqueles que não podem mover-se (DANTE, 1979, II e XXIII, pp. 153 e 172; DANTE, II, XXIII 1993, pp. 669 e 691)." Ao tempo futuro, em outro escrito, Beatrice será identificada com a teologia. Pois, "se o sublime dantesco é virgiliano, sua premência é agostiniana (AUERBACH, 2007, p. 115).”Dante biografado por Boccaccio, em Trattarello in laude di Dante, escrita entre 1351 e 1355, e por Leonardo Bruni no opúsculo Le vite di Dante e del Petrarca.

Ora, esta novidade de contar a própria experiência sem se remeter a um universal concreto, como mais tarde Hegel pensara, pôde demarcar a retomada do gênero literário autobiografia, ao final da Idade Média. Somente um homem destacado do comum da vida cotidiana de seus contemporâneos, tendo passado por uma experiência ímpar, salientada da de outros concidadãos contemporâneos, até aquele momento, poderiam contar o que viveu, viu, ouviu, pensou acerca das diferenças entre a sua cultura de matriz cristã romana e a grande outra,

\footnotetext{
13 "Agostinho não era simplesmente um homem que, tendo ignorado anteriormente as leis aceites de Deus e de Cristo, ou, tendo-se desviado delas, 'voltasse' ao seu Senhor e Salvador - mais do que isso, era um homem que procurara para si a verdade por entre inúmeras verdades e tipos de comportamento igualmente aceites, 'oficiais'. Atribuiu tudo isto à graça de Deus - essa era uma parte da verdade que encontrou (HELLER, 1982, p.193).”
} 
a mongol. Na forma de sondagem e do conhecimento do Outro desde a experiência pessoal. Assim, a criação literária de Marco Polo, compõe parte do novo cenário político cultural da secularização, em movimento desde o século XII, nas cidades do Norte da Itália, mais precisamente nas regiões da Lombardia, da Toscana e de Veneza. Secularização que, grosso modo, significa trocar a eternidade da revelação religiosa pelo horizonte temporal do século, em movimento de baixar o céu à terra. No caso, trocar a futura Cidade de Deus, a esta altura da História perpassada de metamorfoses, pelos desejos humanos espelhados na vida dos negócios e da política, - a vita activa. De modo a dar consistência prática à redescoberta da cidade terrena, como ao tempo dos pagãos antigos. O pano de fundo mais geral fora a incipiente ruptura com a fixidez das classes sociais antigas e medievais, - formadas por aristocratas e escravos ou servos, que, na Antiguidade, favorecera a criação da ética, a consolidação das grandes religiões e a invenção do poder crítico da razão, a filosofia, entre os séculos VIII e II antes do advento do Homem-Deus -, frente ao fato social inaugural do surgimento da nova e plástica classe burguesa, de par com o fenômeno da secularização.

Contudo, o livro de Marco Polo, como hipótese, pode ser considerado o ponto intermediário entre Confissões, de Agostinho, sob os desígnios da vita contemplativa, e os alvores da retomada da vita activa, desde Petrarca movido por cartas de Cícero a seus discípulos, pautada por negócios e política. Em verdade, O Livro das maravilhas, do Veneziano, apresenta-se como o meio termo entre a vida referida a Cristo, de Agostinho, e, para o caso de Polo, a referida a de Kublai Khan. Porém, voltada para a vida política despótica, as guerras de conquista, os negócios, a propriedade de terras e de homens. Registrado no vídeo Ética, ${ }^{14}$ de meados dos anos 1990, do século passado, Gerd Bornheim afirmou que O Livro das maravilhas: a descrição do mundo, de Marco Polo (1254-1324), ditado a Rustichello da Pisa, quando ambos estiveram encarcerados como prisioneiros de guerra, da guerra entre Veneza e Gênova, cadernos do cárcere -, teria sido a primeira autobiografia, a reinaugurar o gênero literário como modelo para a Modernidade. ${ }^{15}$

\footnotetext{
${ }^{14}$ Ver BORNHEIM, G.; CHAUÍ, M., "O drama burguês”, In Ética, Concepção e roteiro de Adauto NOVAES; direção de arte de Dario Vizeu e Paulo Morelli, acessado pelo link https://www.youtube.com/watch?v=I6BrqfJaaqM, dia 14 de abril de 2021.

${ }^{15}$ Contudo, a questão do gênero literário do relato poliano, após tantas traduções e reescritas, apresenta-se de modo mais complexo quanto a sua classificação, complementar ao enquadre como de autobiografia, segundo Bornheim. A propósito, ver BUSANELLO, M. R., "Quanto ao gênero", In $O$ maravilhoso no relato de Marco Polo, dissertação, Letras - Língua, Literatura, Cultura Italianas, USP, 2012, pp. 65-75. http://www.teses.usp.br/teses/disponiveis/8/8148/tde-12032013-091351/pt-br.php, acessado dia 14 de abril de 2021.
} 
Na obra, um homem comum, filho de um mercador, burguês, veneziano, seguindo a rota da seda, participa de uma missão diplomática encomendada pelo Papa, e, no mesmo passo, em que faz negócios, na corte de Kublai Khan, o Grande Khan, o soberano perfeito, o despotês, - em verdade, perfeito organizador da burocracia estatal, pois os reis e barões estiveram a serviço da ordem política econômica do Império $-{ }^{16}$ por, praticamente, dezessete anos. Marco Polo um homem singular, sem nenhuma nobreza herdada de familiares, que jamais poderia identificar-se com qualquer universal concreto, viajara pelo Império Mongol. Retornando à Itália, o Veneziano relata em livro sua experiência frente aos supostos exotismos daquela civilização formadas por diferentes etnias, desde os costumes, aparentemente, muito distintos dos modos europeus cristãos.

O relato causou impacto em vista das novidades e das excentricidades dos mongóis. Os dois primeiros livros relativos a China, - o terceiro cuida da Índia -, tratam do poder despótico do Grande Kahn e da dura justiça realizada em sua corte, compostos com a política de expansão e de consolidação territorial, nas guerras de conquista por toda Ásia. ${ }^{17}$ Além das mazelas, das idiossincrasias, dos aspectos fortuitos do inconsciente coletivo dos mongóis, avant la lettre. Pois, a descrição dos costumes revela um tipo de vida calcada no servilismo, sem porosidade nem imaginação artística, voltada à indústria de tecidos finos e brocados, ao comércio de pedras preciosas, de ouro, prata, além das festas civis e comemorativas das façanhas do Grande Khan. Sob a capa de uma concepção empírica e naturalista de vida. Marco Polo revela a vida do Grande Outro, o antípoda do Ocidente, realizador, poderoso, sem limites ao seu desejo de conquista, como a encarnar, na forma de farsa, certa faceta do espírito trágico antigo: sem medo da vida, da doença, da morte, da perfídia. - Os relatos são de pura externalidade, sem nenhum registro de internalidade, do logos interno de Marco Polo.

\footnotetext{
16 "A chave explicativa deste modo de produção (se) encontra na ausência da propriedade privada do solo, sendo o reino o único proprietário (TRAGTENBERG, 1974, p. 53)."

${ }^{17}$ Em verdade, os livros detalham aspectos do maravilhoso aos ocidentais: exército de milhares de soldados; uso da pólvora e primeiras armas de fogo (YERASIMOS, 2015, p. 29); vitórias nas guerras e boa fortuna nas batalhas; burocracia; correio; astrologia, augúrios e presságios; elementos escatológicos, desde a lenda do reis Magos, da Pérsia, perfilados pelo zoroastrismo ou cripto-cristianismo; diversas formas de casamentos e lugar das mulheres; pedras preciosas, diamantes, rubis, pérolas, lápis lazuli; abundância de ouro, prata e joias vindas da Índia; homens com dentes de ouro; emissão de papel moeda; variadas línguas próprias de cada povo avassalado ao Grande Khan; incineração dos mortos; antropofagia; cristianismo de tradição nestoriana, islamismo, idolatria e povos sem religião; Vatigai, deus único dos tártaros, deus terrestre, a cuidar dos filhos, trigo e gado (YERASIMOS, 2015, p. 29); força dos milagres; adoradores do fogo; longevidade dos monges idólatras; alimentação e condimentos, pimentas branca e preta, gengibre, canela, açafrão; vinho de arroz fermentado e especiarias; vinho de trigo; abundância de feras, leão, búfalo, rinoceronte, elefante, animal de grande inteligência; petróleo, avant la lettre; tatuagens; luxúria; eunucos; seda, cetim, musselina, brocados de ouro; porcelana; aloés e sândalo; pedra que incendeia, o carvão; remédios do fel de serpentes; almíscar; desertos; muros e muralhas; jardins; fogos de artifícios; respeito à vontade dos mortos; escambo; grandes mercados, e, em larga medida, a vida cotidiana dos homens daquela banda da Terra, sob o modo de produção asiático.
} 


\section{Autobiografia ao tempo da civilização do Renascimento}

Se, durante a Antiguidade e a Idade Média, ser considerado indivíduo fora privilégio de poucos, registrados em biografia pela pintura de retratos e autorretratos, com o acúmulo crescente de riqueza do homem burguês, que nunca fora nem seria rei, santo, herói, mas por ser homem comum interessado na vida deste mundo, abre-se a possibilidade de ter uma vida mais atrativa e dinâmica que a dos arquétipos antigos e medievais. Em consequência, o homem que conquistava o mundo, que nasceu para conquistá-lo, escreverá sua autobiografia para contar as particularidades de sua existência de glória e de fama, vez que o horizonte do mundo a ser construído desde a nova ordem social não será mais o do "vale de lágrimas" medieval, mas o lugar de realização material da vida, dos prazeres, dos desejos, sublimados há séculos.

Ao tempo do movimento de extroversão ${ }^{18}$ no âmbito da civilização do Renascimento, sob o teto do ateísmo prático, dois homens ilustres se autobiografaram: Benvenutto Cellini e Girolamo Cardano $^{19}$. O primeiro, escultor, ourives, escritor de um tratado de ourivesaria e, ainda, poeta bissexto. ${ }^{20} \mathrm{Em}$ verdade, escrevera sua autobiografia para escapar de ser biografado por Giorgio Vasari, em Le vite de più eccellenti pittori, scultori e architetti, obra fundadora da história da arte. No entanto, Heller escreve que "Cellini viu em Vasari, e todos os seus contemporâneos, lutadores 'capazes de apunhalar pelas costas' (aliás, descreve-se a si próprio como tal).” Para mostrar a não excepcionalidade de Cellini, Heller registra que o "indivíduo só podia realizar-se contra os outros. [...] Se lermos as vidas dos grandes artistas contadas por Vasari, só encontraremos homens invejosos e ambiciosos, com a única exceção de Donnatelo

\footnotetext{
${ }^{18}$ Para Agnes Heller, “o Renascimento constituiu uma época de grandes personalidades multifacetadas. [...] Entre a grande diversidade de personalidades surge, no entanto, repetidamente, uma característica comum, que consiste num voltar-se para o mundo, aquilo que hoje chamamos, usando uma expressão da psicologia, [...] extroversão. Este voltar-se para o mundo foi característico até ao século XVI, momento em que, com o aprofundar da crise dessa época, cedeu lugar a um afastamento do mundo, à retirada dos homens para os seus problemas interiores e para a 'introversão'. Este nítido corte histórico é a melhor prova de que a 'extroversão' e a 'introversão' não constituem formas inatas do comportamento humano, sendo pelo contrário originadas pelas necessidades e possibilidades da época [...]. A típica falta de interioridade do indivíduo do Renascimento nunca será excessivamente sublinhada (HELLER, 1982, p. 163).”

${ }_{19}$ Acerca de autobiografias destacadas ao tempo do Renascimento, Burckhardt considera também a de Luigi Cornaro, "conhecido filósofo da vida prática", intitulada Discorsi della vita sóbria, ver BURCKHARDT, 1991, p. 247-249.

${ }^{20}$ A propósito, sua autobiografia, La Vita, principia com um soneto: "Questa mia vita travgliata io scrivo / per ringraziar lo Dio della natura, / che mi diè l'alma e poi ne à uto* cura: / alte diverse 'mprese ho fatte e vivo. // Quel mio crudel destin d'offes' à privo / vita or gloria e virtù più che misura, / grazia valor beltà cotal figura / che molti io passo e chi mi passa arrivo. // Sol mi duol grandemente or ch'io cognosco / qual caro tempo in vanità perduto: / nostri frágil pensier se 'n porta 'l vento. // Poi che 'l pentir non val, satrò contento / salendo qual io scessi il Benvenuto / nel fior di questo terren tosco (CELLINI, 1996, p. 3).” (*uto: avuto).
} 
e, até certo ponto, de Michelangelo. [...] Vasari descreve toda esta inveja e ambição como sendo perfeitamente naturais (HELLER, 1982, p. 164)."

Cellini, em $\mathrm{La}$ Vita, ${ }^{21}$ escrita entre 1558 e 1568, relata que matara maridos ofendidos em duelos justos, sugere ser bissexual, vangloria-se de ter atirado na soldadesca de Carlos V, das janelas do Palácio Sant'Angelo, durante o Saque de Roma, em 1527, conta da superioridade técnica do seu trabalho, declara seu amor a Florença e completamente feliz por ter nascido naquele paese. Contudo, para Burckhardt, em sua autobiografia, "Cellini não se dedica exatamente à contemplação da própria interioridade. Todavia, retrata o homem por inteiro - por vezes, a contragosto - com uma verdade e plenitude arrebatadoras (BURCKHARDT, 1991, p. 245)." Mesmo que suas obras mais destacadas "permaneçam como meros esboços e que, como artista, [...] se afigura completo em sua pequena especialidade decorativa, [...] o homem Benvenuto continuará [...] a interessar aos homens até o final dos tempos (BURCKHARDT, 1991, pp. 245-246)."

À sua vez, Girolamo Cardano (1501-176), matemático, médico, astrólogo, jogador de jogos de azar - uma das invenções do Renascimento (sic) -, em De propria vita liber ou De propia vita, ${ }^{22}$ escrita "dal duo inizio fino ad oggi, fine ottobre del 1575", conta "la carcerazione del 1570-1571 a Pavia", ocorrida no "Il 6 di ottobre di quell'anno (1570) fui incarcerato ma, a parte la perdita della libertà, fui tratatto umanamente; il 9 gennaio del '71, nell'ora e nel giorno in cui ero stato impriginato, cioè il venerdi verso sera, tornai a casa, in libertà vigilata (BIANCHI, 2007, p. 410)", que por volta de 1560 entrou para "il carcere al matrimonio", que seu filho cometeu o crime de uxoricídio, que esteve impotente por vinte e dois anos devido a uma conjunção astral, desfavorável, que pensou em abandonar a medicina para dedicar-se somente aos jogos de azar, - combinados com o estudo da matemática e os primórdios da teoria da probabilidade -, que curou o bispo de Paris de uma moléstia grave, perdendo assim a oportunidade de abandonar a profissão dado advento da fama de excelente médico. Porém, conta ter sido péssimo jogador, vingativo, ofensivo nas palavras, sem arrependimento das ofensas cometidas, que pretendera pesquisar da natureza de modo objetivo, o que resultou em um acúmulo de saber organizado. Aos 76 anos, estava feliz, com alguma riqueza, amigos influentes, privilégio, prestigio, conhecedor de segredos, tendo mantido a crença em Deus e

\footnotetext{
${ }^{21}$ O título original, registrado pelo amanuense era Vita di Benvenuto Cellini / oreficie et scultore schritta / di sua mano propria. - Empós, abandonado.

${ }^{22}$ A propósito, conferir BIANCHI, L., "Autobriografia e morale nel Carcer cardaniano", In BALDI, M. e CANZIANI, G. (Orgs.), Girolamo Cardano. Le opere, le fonti, la vita, a cura di Marialuisa Baldi e Guido Canziani,Milano, FrancoAngeli, 2007, 409-425.
} 
quinze dentes. Assim, Cardano parece insinuar a um tanto do logos interno, desde o logos proferido. Anunciando o caminho para a virada da introversão.

Para Agnes Heller, o "egoísmo do Renascimento era um egoísmo de criação. Não estava orientado meramente para a particularidade do ser humano individual, mas primeiramente e acima de tudo para o seu trabalho. [...] (Assim) o indivíduo se fundira com a sua obra, (pois) os homens ainda não tinham aprendido a diferenciar entre o amor próprio e o interesse próprio, entre a autopreservação e o egoísmo (HELLER, 1982, p. 165).” Ao tempo da virada renascentista de retorno à introversão, de certa forma, como modo de recuo moral, talvez, sob o efeito primário das guerras de religiões, entre católicos e calvinistas, em França (VIVANTI, 1963), dois filósofos escreveram autobiografias, diga-se, autobiografias intelectuais, cada qual a seu modo. Primeiro, Montaigne, que, nos Ensaios, escreveu ser ele o único objeto do livro: "só o escrevi para mim mesmo [...] sou eu mesmo a matéria deste livro", datado de "primeiro de março de 1580". Montaigne registrou também que a "opinião pública nada tem a ver com o nosso pensamento, mas o resto, nossas ações, nosso trabalho, nossas fortunas, e nossa própria vida, cumpre-nos colocá-las a serviço da coletividade e submetê-lo a sua aprovação (MONTAIGNE, 1980, XXIII, p. 62).” Após, ainda ao compasso da crise social, Descartes, em o Discurso do Método, registra sua autobiografia intelectual, tão somente, sem nenhuma concessão às paixões, que isolara de modo a refletir em o Tratado das Paixões, ainda, assim, sem expressão da interioridade.

Em passo posterior, de retorno à matriz do estilo introspectivo de registrar as memórias, distante da efervescência do mundo burguês, Vico escrevia, em Napoli, Vita di Giambattista Vico scritta da se medesimo (1723-28), (Vida escrita por si mesmo), até hoje pouco lida. Após, em 1782, Rousseau em Confissões, escancarou, no limite da discrição registra a narração de si, de sentimentos íntimos, misturando certa imaginação poética com dados factuais e filosofia. Reinaugurando deste modo o gênero da autobiografia ao sopro do romantismo, fecundando uma geração de homens destacados, como Goethe, que deixou formidável memória da sua vida, tão agitada e inquieta, em Aus meinem Leben: Duchtung und Wahrheit (De minha vida - poesia e verdade). A autobiografia do Alemão principia com a descrição dos "aspectos benfazejos" do seu mapa astral, cuja "constelação era auspiciosa", ao momento do seu nascimento em Frankfurt, "aos vinte e oito dias de agosto de 1749, quando os sinos dobravam a décima segunda badalada do meio-dia" (GOETHE, 2017, p. 25)." Até a modestíssima The Autobiography of Charles Darwin - 1809-1882 (Autobiografia), de Charles Darwin, concluída aos três de agosto de 1876. Obra publicada de forma mutilada na primeira 
edição, dado o excessivo moralismo familiar. Ao final, o Biólogo registra: "Tenho hábitos metódicos, o que foi bastante útil para minha linha particular de trabalho. [...] Assim, meu sucesso como homem de ciência, qualquer que tenha sido o tamanho, tanto quanto posso julgar, foi determinado por qualidades e estados mentais complexos e diversificados. Dentre eles, os mais importantes foram: o amor à ciência, a paciência ilimitada na longa reflexão sobre qualquer assunto, o empenho na observação e na compilação de fatos, e uma dose razoável de criatividade e bom senso. Com as moderadas habilidades mentais que possuo, é realmente surpreendente, portanto, que eu tenha influenciado, em medida considerável, as crenças dos cientistas sobre algumas questões importantes (DARWIN, 2000, pp.26-127)." Sem olvidar de autobiografias frutos de longas entrevistas, como a de Mauricio Tragtenberg cedida em setembro de 1983, condensada em Memórias de um Autodidata no Brasil (1999). ${ }^{23}$

\section{Biografias a várias mãos, no cinema e poética}

Nietzsche, ao correr da segunda metade do Século XIX, alertara para a epidemia de biografias lançadas da parte de pessoas sem muita relevância intelectual e política, como mero exercício de exibicionismo público e desgraça aos desavisados leitores. Contudo, Nietzsche interessava-se pela psicologia profunda da vida dos grandes filósofos, na esperança de encontrar aquilo que, pessoalmente, os levara a pensar e a escrever o que pensaram e escreveram. ${ }^{24} \mathrm{Na}$ mesma época, Marx, que dizia não desejar ser biografado, por ironia, finda por obter duas biografias, uma para o jovem e outra para o velho: a de Michael Heinrich, Karl Marx e o nascimento da sociedade moderna (1818-1841), e, outra, de Marcelo Musto, O Velho Marx: uma biografia de seus últimos anos (1881-1883), ambas editadas em 2018.

Todavia, o que pode ser melhor comparado ao prazer da leitura de biografias e autobiografias? Desde prosaicas biografias, como a de Dashiell Hammett, autor de romances policiais, alinhados pela ficção noir, que lera a Crítica da razão pura, aos treze anos, e se decepcionara, pois não revelava "todas as respostas da vida (JOHNSON, 1986, 31)." Ou o denso álbum de retratos de Lilian Hellman, Pentimento, desde o título, que, dentre outros personagens, relata de modo ficcional e não ficcional o complexo relacionamento com

\footnotetext{
${ }^{23}$ O livro resulta de entrevista concedida a Carmen Lúcia Evangelho Lopes, Pedro Paulo Manus, Beatriz Tragtenberg e Jucirema Quinteiro, na sede da Oposição Sindical Metalúrgica de São Paulo.

${ }^{24}$ Nietzsche a estibordo. "Uma longa experiência, trazida por tais andanças pelo proibido, ensinou-me a considerar de modo bem diferente do desejável as razões pelas quais até agora se moralizou e se idealizou: a história oculta dos filósofos, a psicologia de seus nomes surgiu-me às claras. Quanta verdade suporta, quanta verdade ousa um espírito? (NIETZSCHE, "Prólogo", § 3, 1995).
} 
Hammett. E o angustiado Retrato Calado, do filósofo Luiz Roberto Salinas Fortes, a revisitar os tempos de prisão e a tortura, mostras de interioridade por cicatrizes físicas e morais. Ainda, Sartre, em As palavras, de saída, livrando-se do superego paterno. Até a fineza do espírito registrada em A asa do dragão, do cronista mineiro Jurandir Ferreira, a pendular entre o viés ficcional e os fatos alegorizados da vida, em lance de porosidade para a vida interna. Além de autor da coletânea de crônicas, intitulada Da quieta substancia dos dias.

Contudo, ao final da década de setenta do século passado, surgiu o elegantíssimo Esboço de Figura, ${ }^{25}$ - título retirado do poema de Drummond, que abre o livro -, uma coletânea em homenagem ao Professor Antonio Candido (1918-2017), dedicado aos seus setenta anos. Uma espécie de biografia escrita a muitas mãos amigas, por colegas de ofício e admiradores de sua vida e obra. Publicada ao tempo que aposentara da USP, sem, contudo, abandonar a vida acadêmica e cultural, como crítico literário, de par com a de ator político influente e discreto, como fizera ao participar ativamente da criação do PSB, nos anos cinquenta, ao escrever para os jornais Folha Socialista e Vanguarda Socialista, ou participando da fundação do PT. Após, Vinicius Dantas pulicou Bibliografia de Antonio Candido ${ }^{26}$ título que dispensa comentário. Naquela época, Antonio Candido cedera entrevista a Tatiana Belink, ${ }^{27}$ em que contara os seus anos de formação na mantiqueira Poços de Caldas, desde o curso no gimnasio e no colégio, frequentados no Colégio Municipal, onde fora aluno de Edmundo Gouvêa Cardillo, formado em Direito, sobretudo, professor de língua portuguesa e literatura, autor do intrigante Dante, seiscentos anos de dúvida. ${ }^{28} \mathrm{Na}$ entrevista, Candido disse que escrevia uma redação de dez páginas e o professor Edmundo Cardillo a devolvia com quinze páginas de anotações e sugestões. ${ }^{29}$ - Assim, se forma um intelectual.

O cinema produziu biografias oportunas, mesmo que parciais, de filósofos, como a de Giacomo Leopardi, em Il Giovane Favoloso, direção de Mario Martone, de 2014, sob tratamento afetivo familiar e os ares de Napoli, terrível e maravilhosa. Incontornável, a fina pesquisa da vida, obra e correspondência, transformada em Dias de Nietzsche em Turim, por

\footnotetext{
${ }^{25}$ LAFER, C. (Org.), Esboço de Figura: homenagem a Antonio Candido, São Paulo, Duas Cidades, 1979.

${ }^{26}$ DANTAS, V., Bibliografia de Antonio Candido, São Paulo, Duas Cidades / Editora 34, 2002. (Coleção Espírito Crítico".

${ }^{27}$ Ver ABRAMOVICH, F., "Os mestres dos grandes mestres", In São Paulo, Summus, 1985, pp. 88-113.

${ }^{28}$ CARDILLO, Edmundo Gouvêa, Dante, seiscentos de dúvida, São Paulo, Aquarius, 1976.

29 "No ginásio, alguns professores me marcaram muito... Tive um professor de português excepcional, Dr. Edmundo Gouvêa Cardillo, que nos incutiu o senso da língua portuguesa. Exigia que lêssemos todos os dias poemas, que deveríamos saber de cor (eu acho muito bom saber de cor as coisas, pois aí se pode trabalhar a cadência, a leitura verdadeira etc.). fazíamos composições e ele devolvia todas elas, com folhas de comentários, feitos em tinta vermelha... Eram composições de dez páginas e recebiam um comentário de quinzes páginas (CANDIDO, In ABRAMOVICH, 1985, p. 91)."
} 
Júlio Bressane, de 2002. Antecedido da abordagem política da vida do filósofo renascentista, em Giordano Bruno, de Giuliano Montaldo, 1973. Sem prescindir dos filmes de Roberto Rosselini, oportuno e sagaz biógrafo cinematográfico de Sócrates, Agostinho, Descartes. Por fim, o filme em que vida e obra se fundem, Notícias da Antiguidade Ideológica: Marx, Eisenstein, O Capital, direção de Alexander Kluge, três dvds, de 2008, com participações de Hans Magnus Enzensberger, Peter Sloterdijk e do poeta Durs Grünbein. Filmado a partir da resolução artística de Sergei Eisenstein: "a decisão está tomada: irei filmar O Capital, segundo roteiro de K. Marx - esta é a única saída formal possível” (1927). ${ }^{30}$ Fala plena de significados dirigida, certamente, ao futuro, como se verifica.

Walt Whitman, a propósito, em Folhas da Relva, anuncia que a obra poética figura qual uma autobiografia, como se lê no verso final, "Pretendo, para uso próprio, traçar aqui", do poema "Enquanto eu lia o livro", em epígrafe.

Da tensão entre os logoi interno e o proferido, das fisionomias interna e externa, aos arremates da extroversão e da introversão, talvez a biografia possa voltar a ser a narrativa da vida de homens comuns, como aos primórdios da Idade Moderna. E da autobiografia se dirá: “Esses homens! Todos puxavam o mundo para si, para o concertar consertado. Mas cada um só vê e entende as coisas dum seu modo (GUIMARÃES ROSA, 2006, p. 13)." Vez que a exterioridade e a interioridade das biografias e das autobiografias se tocam, sem se entrecruzarem, por tangências e secâncias. - Porém, quanto de verdade suportam? Por certo, o necessário para o caso dos relatos de vida escritos para si mesmo.

\section{REFERÊNCIAS BIBLIOGRÁFICAS}

ABRAMOVICH, F., "Os mestres dos grandes mestres", In Quem educa quem?, $7^{\text {a }}$ edição, São Paulo, Summus, 1985, pp. 88-113.

ARGAN, C., Clássico Anticlássico: o Renascimento de Brunelleschi a Bruegel, tradução Lorenzo Mammì, São Paulo, Cia. das Letras, 1999.

AUERBACH, E., "Os apelos ao leitor em Dante", In Ensaios de literatura ocidental: filologia e crítica, tradução Samuel Titan Jr. e José Marcos Mariani de Macedo, São Paulo, Duas Cidades / 34, 2007, pp. 111-132.

BALDI, M. e CANZIANI, G. (Orgs.), Girolamo Cardano. Le opere, le fonti, la vita, a cura di Marialuisa Baldi e Guido Canziani,Milano, FrancoAngeli, 2007.

\footnotetext{
${ }^{30}$ A propósito, conferir o poema de Vinicius de Moraes, "Tríptico na morte de Sergei Mikhailovitch Eisenstein", escrito em Los Angeles, aos 12 de fevereiro de 1948 (MORAES, 1987, pp. 266-267). O poema dá a ver o rasgado elogio da vida e da arte do cinema de Eisenstein, contando como parte de sua biografia.
} 
BACARAT JR., J. C., "PORFÍRIO. Sobre a vida de Plotino e a organização dos livros", In , Enéadas, I, II, III; Porfírio, Vida de Plotino, (Introdução, tradução e notas), vol.I, doutorado em Linguística, Campinas, Unicamp, 2006, pp. 163-208.

BARON, H., En busca del Humanismo Cívico: ensayos sobre el cambio del pensamiento medieval al moderno, México, traducción Miguel Abelardo Camacho Ocampo, Fondo de Cultura Económica, 1993.

BOCCACCIO, G., Vita di Petrarca, a cura di Gianni Villani, Roma, Salerno Editrici, 2004.

, Trattarello in laude di Dante, a cura di L. Sasso, Milano, Garzanti, 2007.

BORNHEIM, G.; CHAUÍ, M., "O drama burguês”, In Ética, NOVAES, A. (concepção e roteiro), Ética, (direção de arte de Dario Vizeu e Paulo Morelli); link https://www.youtube.com/watch?v=I6BrqfJaaqM, acessado dia 31 de maio de 2020. (Ética, vol. 2, "O drama burguês", TvCultura e O2 Filmes - O2, videocultura, NTSC-VHS-Cor, 92' série).

BRUNI, L., Le vite di Dante e del Petrarca, a cura di Antonio Lanza, Roma, Archivio Guido Izzi, 1987.

BURCKHARDT, J., “A biografia”, In A cultura do Renascimento na Itália: um ensaio, tradução Sérgio Tellaroli, São Paulo, Cia. das Letras, 1991, pp. 241-249.

BUSANELlO, M. R., O maravilhoso no relato de Marco Polo, dissertação, Letras - Língua, Literatura, Cultura $\quad$ Italianas, $\quad$ USP, $2012 . \quad$ Link http://www.teses.usp.br/teses/disponiveis/8/8148/tde-12032013-091351/pt-br.php, acessado dia 31 de maio de 2020.

CARDILlO, E. G., Dante, seiscentos anos de dúvida, São Paulo, Aquarius, 1976.

CELLINI, B., La Vita, a cura di Carlo Cordié, Milano-Napoli, maggio MCMXCVI.

DANTE, "Vita Nuova", In _, Tutte le Opere, a cura di Italo Borzi, Roma, 1993, pp. 668714.

, "Vida Nova", tradução Paulo M. Oliveira e Blasio Demétrio, In Sto. Tomás de Aquino, Dante Alighieri, John Duns Scott, William of Ockahm, 2a edição, São Paulo, Abril Cultural, 1979, pp. 151-190. (Coleção “Os Pensadores”).

DARWIN, C., Autobiografia, 1809-1882, tradução Vera Ribeiro, Contraponto, 2000.

DIÔGENES LAÊRTIOS, Vidas e doutrinas dos filósofos ilustres, $2^{\text {a }}$ edição, tradução Mário da Gama Kury, Brasília, UnB, 1977.

FRANGIOTTI, R., "Introdução", In SANTO AGOSTINHO, Confissões, tradução Maria Luiza Jardim Amarante, São Paulo, Paulus, 1997, pp. 9-16.

GARIN, E., Ritratti di umanisti: sete protagonisti del Rinascimento, Milano, Bompiani, 1996.

GOETHE, J. W. von, De minha Vida: poesia e verdade, tradução Mauricio Mendonça Cardozo, São Paulo, Unesp, 2017.

GUIMARÃES ROSA, J., Grande Sertão: veredas, Rio de Janeiro, Nova Fronteira, 2006 (edição comemorativa). 
HELLER, A., "Individualidades, conhecimento dos homens, conhecimento de si próprio, autobiografia", In O homem do Renascimento, tradução Conceição Jardim e Eduardo Nogueira, Lisboa, Presença, 1982, pp. 163-201.

HOMERO, “Afrodite, deusa do amor”, In Hinos Homéricos, tradução Flávia Regina Marquetti, São Paulo, Unesp, 2010, pp. 95-128.

JOHNSON, D., Dashiell Hammett: uma vida, tradução Álvaro Hattnher, São Paulo, Cia. das Letras, 1986.

LAFER, C. (Org.), Esboço de Figura: homenagem a Antonio Candido, São Paulo, Duas Cidades, 1979.

MONTAIGNE, M. E. de, Ensaios, tradução Sérgio Milliet, $2^{\text {a }}$ edição, São Paulo, Abril Cultural, 1980. (Coleção “Os Pensadores”).

MORAES, V. de, "Nossa Senhora de Los Angeles e Nossa Senhora de Paris", In Poesia Completa e Prosa, volume único, Rio de Janeiro, Nova Aguilar, 1987, pp. 249-297.

NIETZSCHE, F., Ecce Homo: como alguém se torna o que é, $2^{\mathrm{a}}$ edição, tradução Paulo César de Souza, São Paulo, Cia. das Letras, 1995.

POLO, M., O livro das maravilhas: a descrição do mundo, tradução Eloi Braga Jr., Porto Alegre, L\&PM, 2015.

PLUTARCO, Vite parallele, cinco volumes, a cura di Antonio Traglia; Domenico Magnino; Maria Luisa Amerio e Domenica Paola Orsi; Domenico Magnino e Gabrielle Marasco, Torino, UTET, 1992, 1992, 2010, 2011, 1992, respectivamente.

SALLUM, J. L. F., Sobre sofística e filosofia no platônico Siriano Filoxeno, "o isocrático”, dissertação em Letras Clássicas e Vernáculas, USP, São Paulo, 2012.

SANTO AGOSTINHO, Confissões, tradução Maria Luiza Jardim Amarante, São Paulo, Paulus, 1997.

TITO LIVIO, Storia di Roma dalla sua fondazione (Ab Urbe Condita Libri), Libro I, 9a edizione, traduzione Mario Scándola, Milano, Rizzoli, 1997, pp. 223-367.

TRAGTENBERG, M., "O modo de produção asiático", In Burocracia $e$ Ideologia, São Paulo, Ática, pp. 21-58.

, Memórias de um Autodidata no Brasil, São Paulo, Escuta, 1999. (Organização Sonia Alem Marrach).

VASARI, G., Le vite de più eccellenti pittori, scultori e architetti, seconda edizione, Roma, Newton, dicembre 1993.

Vida de Michelangelo Buonarroti, tradução Luiz Marques, Campinas, Unicamp, 2011.

VICO, G., "Vita di Giambattista Vico scritta da se medesimo" (1723-28), In Opere, a cura di Andrea Battistini, Milano, Arnoldo Mondadori, maggio 2007, pp. 5-85. , Vida escrita por si mesmo (1728), tradução Ana Cláudia Santos, Lisboa, Calouste Gulbenkian, março 2017.

VIRGÍlIO, Eneida, tradução Carlos Alberto Nunes, São Paulo, 34, 2014 (edição bilíngue). 
VIVANTI, C., Lotta política e pace religiosa in Francia: fra Cinque e Seicento, Torino, Einaudi, 1963.

WHITMAN, W., Folhas de Relva. Edição do leito de morte, tradução Bruno Gambarotto, São Paulo, Hedra, 2011. (Leaves of Grass).

YERASIMOS, S., "Sob os olhos do Ocidente", In POLO, M., O livro das maravilhas: a descrição do mundo, tradução Eloi Braga Jr., Porto Alegre, L\&PM, 2015, pp. 9-34.

\section{Filmografia}

Dias de Nietzsche em Turim, direção Júlio Bressane, Brasil, Europa Films, 2002.

Giordano Bruno, direção Giuliano Montaldo, Itália, Versatil Home Vídeo, (1973), dvd 2011.

Il Giovane Favoloso, direção Mario Martone, Itália, Palomar / Rai Cinema, 2014.

Notícias da Antiguidade Ideológica: Marx, Einsenstein, O Capital, direção Alexandre Kluge, três dvds, Alemanha, Versatil Home Vídeo, 2011.

Sampa, Outono de 2021. 